\title{
Application of GC in the Analysis of Carbohydrates
}

\author{
Author: Ghayth Mohammed Ghayth* \\ Chemistry Department, Faculty Of education, Bani Walid University, Bani Walid, Libya \\ Corresponding author E-mail: dr.ghayte.ali89@gmail.com
}

\begin{abstract}
In the mid-1970s and before, Gas Chromatography was the leading technique for analysing carbohydrates in foods until when HPLC start to dominate. Never the less, GC still offers advantages for many applications of food technologists in carbohydrates. The efficiency of the detection of these molecules is reduced as a result of the high polarity and un-volatility of sugars. To overcome these problems, the sugars can be derivative by removing the active hydrogen such as $-\mathrm{OH}$, consequently increasing volatility and improving detectability. Acylation reaction is the most commonly used method of derivatization.
\end{abstract}

However, GC analysis is limited to derivative sugars of low molecular weight where Carbohydrates up to 12 mono saccharides unit could be analysed and structural determination of poly saccharides. Regularly, one step reactions are preferred but sometimes two steps reactions are good when derivative show better chromatographic behaviour.

To sum up we can conclude that preparation of derivatives for different types of carbohydrate are necessary before GC analysis because Derivatives would reduce the number of peaks in order to obtain better information and structure of the samples.

Keywords: Gas Chromatography, analysis, acylation, carbohydrates and derivatives. 


\section{Introduction}

The first report on gas chromatography analysis of carbohydrates was in 1958 but it was the application of the tri methyl silylation technique to carbohydrates by Sweeley and co-workers (1963) that initiated the rapid development of work in this field. GC was the leading technique for analysing carbohydrates in foods until the mid-1970s when HPLC start to dominate. Never the less, GC still offers advantages for many applications of food technologists in carbohydrates.

Carbohydrate such as mono saccharides are very difficult to analyse by GC, due to decomposing in the injector port and "crashing" out on the column. The efficiency of the detection of these molecules is reduced because of the high polarity and un-volatility of sugars. To overcome these problems, the sugars can be derivative by removing the active hydrogens such as $-\mathrm{OH}$, therefore increasing volatility and improving detectability. The most commonly used method of derivatization for the analysis of sugars is an acylation reaction, Which involves converting the active $\mathrm{H}$ into tri-fluroesters via a carboxylic derivative. The ester in the derivative sugar improves the volatility, which makes it easier to analysis by GC/FID MBTFA, like the majority of derivatization reagents, produces a by-product.

Gas chromatography required a sample being vaporised and injected onto the head of the chromatographic column. The sample is moved through the column by the flow of gas (mobile phase). The column itself contains a liquid (stationary phase) which is adsorbed onto the surface of an inert solid.

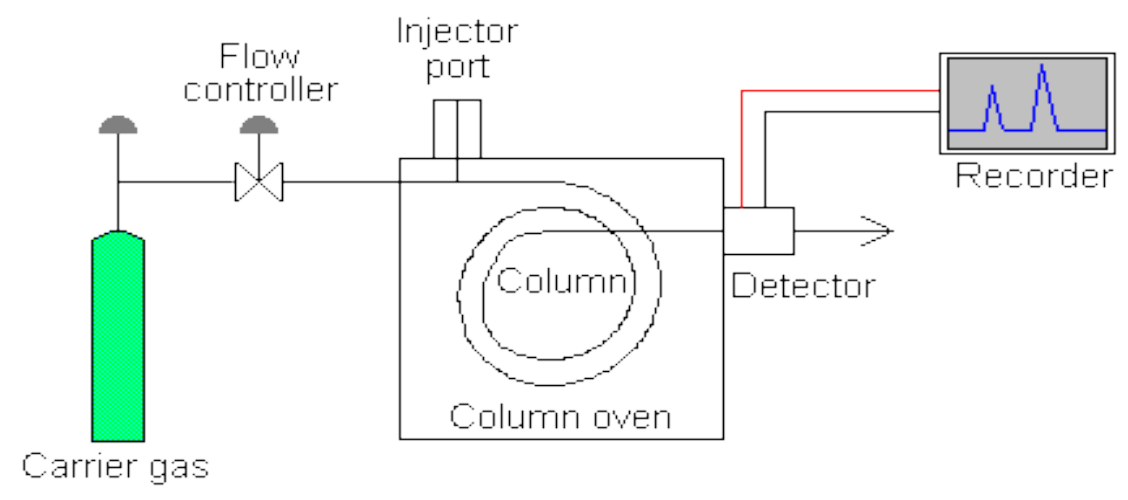

Figure (1) shows the Diagram of gas chromatograph 


\section{Instrumental components}

\section{1-Carrier gas}

Nitrogen, helium, argon, and carbon dioxide are the most commonly used gases.

\section{2-Sample injection port}

A micro syringe is used to inject sample through a rubber septum into a flash vaporiser port at the head of the column. The temperature of the sample port is higher by $50 \mathrm{C}^{0}$ than the boiling point of the least volatile component of the sample.

\section{3-Columns}

Packed and capillary (also known as open tubular) are the two general types of columns.

\section{4- Detectors}

There are many detectors of GC such as 1- non-selective detector responds to all compounds except the carrier gas. 2- Selective detector responds to a range of compounds with a common physical or chemical property. 3- Specific detector responds to a single chemical compound.

GC analysis is limited to derivative sugars of low molecular weight. Mainly, mono-saccharides, di-saccharides and tri-saccharides by using suitable derivatives and right conditions.

Carbohydrates up to 12 mono saccharides unit could be analysed and structural determination of poly saccharides.

One-step reactions are preferred but sometimes two steps reactions are good when derivative show better chromatographic behaviour. Classical derivatization method is substitute polar groups of carbohydrate in order to increase their volatility. [1,2]

\section{Some of common carbohydrate derivatives}

1-common sugars \{poly alcohols and neutral saccharides\}

a) Methyl ethers

$$
\mathrm{ROH}+\mathrm{CH}_{3} \mathrm{X} \longrightarrow \quad \mathrm{ROCH}_{3}+\mathrm{HX}
$$


It is good for analysing low molecular weight carbohydrates and for structural analysis of poly sacharides .Never the less; it is a complex method due to different tautomeric forms.

b) Acetates

$\mathrm{ROH}+\mathrm{AC}-\mathrm{X} \longrightarrow \mathrm{RO}-\mathrm{AC}+\mathrm{HX}$

It is suitable for thermal and chemical compounds but it is low volatile than (a)

c) Tri fluoro acetate

\section{$\mathrm{ROH}+\mathrm{CF}_{3} \mathrm{CO}-\mathrm{X} \longrightarrow \quad \mathrm{R}-\mathrm{O}-\mathrm{COCF}_{3}+\mathrm{HX}$}

It's useful for carbohydrates with a wide range of molecular weight and more volatile than (b)

But it is hard to achieve a satisfied quantification.

d) Tri methyl silyl ethers

\section{$\mathrm{ROH}+\left(\mathrm{CH}_{3}\right)_{3} \mathrm{Si}-\mathrm{X} \longrightarrow \quad \mathrm{R}-\mathrm{O}-\mathrm{Si}\left(\mathrm{CH}_{3}\right)_{3}+\mathrm{HX}$}

The aspects of this method are: increasing the volatility, thermal stability, less polarity, large number of silyl reagents are available and it is useful for quantifying equilibrium forms of carbohydrate in solution. However, it is a complex chromatographer and the sample should be dried.

e) Tri methyl silyl oximes

$$
\mathrm{R}-\mathrm{CHOH}-\mathrm{CHO}+\mathrm{NH}_{2} \mathrm{OH} \longrightarrow \quad \mathrm{R}-\mathrm{CHOH}-\mathrm{C}=\mathrm{NOH}+\mathrm{H}_{2} \mathrm{O}
$$

$$
\mathrm{R}-\mathrm{CHOH}-\mathrm{C}=\mathrm{NOH}+\left(\mathrm{CH}_{3}\right)_{3} \mathrm{Si}-\mathrm{X} \longrightarrow \quad \mathrm{R}-\mathrm{CHO}-\mathrm{Si}\left(\mathrm{CH}_{3}\right)_{3}-\mathrm{CNO}-\mathrm{Si}\left(\mathrm{CH}_{3}\right)_{3}+\mathrm{HX}
$$

This procedure is applicable for aldoses and ketoses. The derivatives are stable for long time

f) Aldo-nitrile acetate
(1) $\mathrm{R}-\mathrm{CHOH}-\mathrm{CHO}+\mathrm{NaBH}_{4}$
$\mathrm{R}-\mathrm{CHOH}-\mathrm{CH}_{2} \mathrm{OH}$
(2) $\mathrm{R}-\mathrm{CHOH}-\mathrm{CH}_{2} \mathrm{OH}+\mathrm{Ac}-\mathrm{X} \longrightarrow$
$\mathrm{R}-\mathrm{CHOAc}-\mathrm{CH}_{2} \mathrm{O}-\mathrm{Ac}+\mathrm{HX}$ 
It gives only one product for each aldose. There is no water in the reaction. Formation of nonvolatile products of aldoses and ketoses are exist simultaneously.

g) Di-alkyl di-thio acetate
1) $\mathrm{R}-\mathrm{CHOH}-\mathrm{CHO}+\mathrm{R}^{\prime}-\mathrm{SH} \longrightarrow$
$\mathrm{R}-\mathrm{CHOH}-\mathrm{CH}\left(\mathrm{S}-\mathrm{R}^{\prime}\right)_{2}+\mathrm{H}_{2} \mathrm{O}$
2) $\mathrm{R}-\mathrm{CHOH}-\mathrm{CH}\left(\mathrm{S}-\mathrm{R}^{\prime}\right)_{2}+\left(\mathrm{CH}_{3}\right)_{3} \mathrm{Si}-\mathrm{X} \longrightarrow$
$\mathrm{R}-\mathrm{CHO}-\mathrm{Si}\left(\mathrm{CH}_{3}\right)_{3}-\mathrm{CH}\left(\mathrm{S}-\mathrm{R}^{\prime}\right)_{2}$

It forms one peak for each aldose and the products are thermal and chemical stable but the method is prepare due to the use of thiol as regent of derivatizations.

2-Alditol acetates derivatives $\{$ high retention time $\}$

After reducing carbonyl group of aldoses, the analyte is simplified by the subsequence formation of alditol acetate by producing single peak for ach derivative sugar.

As it formed, alditol acetate make the derivatives become more stable which allowing lean up and storage derivatives for long time, and it has been used for mono analysed .

converting sugar of potato tubers \{including fructose $\}$ to glucitol and mannitol hexa acetate in fixed proportion by adding $1 \mathrm{ml}$ sodium borohydride solution and $0.5 \mathrm{M}$ di methyl sulfoxied and it has to kept at $40 \mathrm{C}^{0}$ for one hour and 30 minute. After leaving one day at $4 \mathrm{C}^{0}$ the sample was acetylated with acetic acid.

\section{$\mathrm{R}-\mathrm{CHOH}-\mathrm{CHO}+\mathrm{NaBH} \longrightarrow \quad \mathrm{R}-\mathrm{CHOH}-\mathrm{CH}_{2} \mathrm{OH} \longrightarrow \mathrm{AC}-\mathrm{X} \quad \mathrm{R}-\mathrm{CHO}-\mathrm{AC}-\mathrm{CH}_{2} \mathrm{O}-\mathrm{AC}+\mathrm{HX}$}

The former derivatisation allowed the estimation of the carbohydrate. Never the less, this procedure consuming much time because of manual processing steps.

\section{3- Ether and Ester}

Methyl ethers and acetate, trifluoro acetate and methylsilyl ethers are the most common derivatizations that used for carbohydrate determination.

TMS is the most popular derivatizations of carbohydrates applied to GC analysis of saccharides and poly alcohols duo to the good volatility and stability characteristics formed derivatizations. 
TMSDEA, MSA, MSTFA and bovine serum albumin BSA have been used for silylation at different temperature for different reaction times. Pyridine is the most solvent used for sugar analysis because of the good solubility of carbohydrates in it.

Sometimes, there is no need for solvent with silylating reagents because they act as a solvent and in other times, addition of hexan and water are recommended in order to eliminate extra reagents or interference of sample. when sugars are dissolved with free carbonyl groups, different derivatization is obtained for each tautomeric form of the sugar and that is leading to appear different peak which producing a complicated chromatogram and this might interfere in quantification and identification of complex sugar mixtures, there for different methods of derivatizations have been conducted in order to reduce the latter effect

\section{4-Oximes $\{$ TMSO $\}$}

Trimethyl silyl oximes are produced in two steps procedure (first step is oximation and the second step is silylation). The derivatizations of carbohydrate show two peaks corresponding to syn (E) and anti (Z) forms. Non reducing carbohydrate - which does not form oximes- shows a single peak.

TMSO derivatizations are suitable for (aldoses and ketoses) and they are used to determined carbohydrates in a complex mixture.

How TMSO are produced?

Firstly, the sample is dissolved in pyridine containing $25 \%$ hydroxyl amine hydrochloride.

Secondly, the solution is heated up for 30 minutes at $75 \mathrm{C}^{0}$. Finally, the silylation step, HMDS and TFA should be added to the mixture. Then, the mixture should be allowed to react for 30 minutes at $45 \mathrm{C}^{0}$. Different derivatizations are applicable to get complementary information of the sample understudy.

There are other alternative to TMSO such as Tri fluoroacetlyated oximes or tri methylsilyl Omethyl oximes (these derivatizations give $\mathrm{E}$ and $\mathrm{Z}$ forms \{isomeric forms\}). almost all $\mathrm{O}$ methyl oximes which formed from aldoses are syn E, while that from ketoses approximately have the same proportion of the forms $\mathrm{E}$ and $\mathrm{Z}$ and this aspect can be used in identification between aldoses and ketoses ( it is an easy method to use for determining glucose and fructose in a serum) 
5) Acids

Fatty acid (FA) group is the only group of carboxylic acids suitable to be separated and quantitated by GC without derivatization and the short chain of hydroxy carboxylic acid in select cases such as lactic and malic acids. GS is preferred in order to have the optimum condition to determine the homologous of series of FAs due to selectivity, sensitivity, better peak shape and short analysis time.

The separation of oleic, stearic, linoleic and linolenic acids of canola seeds without derivatization due to the separation of canola seed's FAs can be performed as their isopropyl esters based on their extraction with isopropyl containing sulphuric acid $\mathrm{H}_{2} \mathrm{SO}_{4}$

6) Amino-sugars

Amino-sugars are monosaccharaides but with $(\mathrm{N})$ atom in the cycle instead of $(\mathrm{O})$ atom. Aminosugars are found in a natural source or can be synthetically produced. It has been used as a drug against cancer or viral infection. Tri-methyl silylation are used to produce Amino-sugar's derivatives. MSTFA is the most suitable derivative of iminosugars due to high stability and volatility for analysis resulting two peaks for each Amino-sugars.

\section{7) Sugar phosphate}

Sugars which have substituted a phosphate group $\left(\mathrm{PO}_{4}\right)$ are used in biological system to transfer or store energy. Sugar phosphate derivative is needed two steps (oximation and silylation) to be prepared in order to use in GC analysis. There too many families of carbohydrate which involve different approach to get derivatives.

\section{8) Amino acids}

amino acids have two functional groups which are amine group $\{\mathrm{N}-(\mathrm{O}, \mathrm{S})\}$ and carboxyl group $\mathrm{COOH}$ and that make it need to derivative by two steps (1) esterification of the carboxyl group by using various of short chain alcohols ( aliphatic alcohols ). (2) Acylation of the amine group by different acid anhydrides. EX: N-hebta fluoro butyryl isopropyl ester derivatives are used in GC-MS analysis to identify free amino acids. [3, 4, 5, 6, 7, 8] 


\section{Examples of application of GC on carbohydrate}

1- Determination of glucose and fructose in clinical sample

The determination of serum level is difficult because of low concentration of fructose and interference from serum glucose.

GC-MS are used for determining glucose and fructose in the serum as methoxime per acetates (MOA) derivatives (aldoses and ketoses).

Enzyme assay is based on using glucose -6- phosphate dehydrogenase $\{\mathrm{G} 6 \mathrm{PDH}\}$ to oxidate glucose as glucose -6 - phosphate $\{\mathrm{G} 6 \mathrm{P}\}$. By phospho glucose isomerase enzyme fructose -6phosphate converted to glucose -6- phosphate and subsequently by G6PDH it is oxidised in the mixture.

The concentration of glucose is determined as the value of the difference in G6P concentration before and after using phospho glucose isomerase enzyme.

The aim of the experiment is quantifying glucose and fructose in clinical sample.

\section{Experiment procedure}

Mono saccharides and stable isotope standard sample have been prepared. Then, plasma "glycolated" was separated from haemoglobin. 0.3 barium hydroxide (300 $\mu 1)$ and 0.3zinc sulphate $(300 \mu \mathrm{l})$ were added to the protein in the serum. The supernant which contain glucose and fructose were collected in order to start derivatization

Derivatization:

Mono saccharides standard and supernant were transferred into glass test tubes and dried by air at room temperature. After that, methoxyl amine hydrochloride (100 $\mu 1,0.18 \mathrm{M}$ in pyridine) was added into both test tubes at $70 \mathrm{C}^{0}$. After 60 minutes, acetic anhydride (100 $\left.\mu 1\right)$ was added into test tubes and left for another 60 minutes at $45 \mathrm{C}^{0}$ in order to allow reacting. After drying, the final step was dissolving the sample in $50 \mu$ l ethyl acetate.

\section{GC-MS analysis}

$2 \mu \mathrm{l}$ of the sample was injected into HP $6890 \mathrm{GC}$ capillary column (30 m x $0.25 \mathrm{~mm} \mathrm{ID,} 0.25$ $\mu \mathrm{m}$ film thickness, injector temperature $180 \mathrm{C}^{0}$, flow rate of $\mathrm{He} 1 \mathrm{ml} / \mathrm{min}$ and split ratio of 2), column temperature was held at $180 \mathrm{C}^{0}$ for $2 \mathrm{~min}$ and increased $5 \mathrm{C}^{0}$ per minute to $250 \mathrm{C}^{0}$ 
before final temperature went up $50 \mathrm{C}^{0}$ to reach $300 \mathrm{C}^{0}$. GC effluent was introduced to the $\mathrm{HP}$ 5973. Mass spectrophotometer for CI and EI analysis in mass range $(50-500 \mathrm{~m} / \mathrm{z})$.

\section{Result}

Table (1) demonstrate Chromatographic retention times, ring, and assigned anomeric configurations and area percentages for authentic monosaccharaides

\begin{tabular}{|l|l|l|l|}
\hline Compound & $\begin{array}{l}\text { Retention time } \\
(\mathbf{m i n})^{\mathbf{a}}\end{array}$ & $\begin{array}{l}\text { Ring configuration and assigned } \\
\text { anomeric configuration }\end{array}$ & \% \\
\hline D-glucose & 21.776 & Pyranose, $\alpha$ & 68.9 \\
\hline & 18.164 & Furanose, $\alpha$ & 31.1 \\
\hline D-xylose & 18.532 & Pyranose, $\alpha$ & 7.5 \\
\hline & 18.987 & Furanose, $\beta$ & 33.8 \\
\hline & 18.280 & Pyranose, $\beta$ & 10.5 \\
\hline & 18.538 & Furanose, $\alpha$ & 48.2 \\
\hline & 18.630 & Furanose, $\beta$ & 12.3 \\
\hline & & Pyranose, $\alpha$ & 34.7 \\
\hline
\end{tabular}

Table (1)

Reduction in retention times may occur due to column performance and ${ }^{\mathrm{b}}$ Area $\%$ based on total ion chromatograms

Table (2) indicates Isotopomer analysis of fragments formed by $\mathrm{C}-\mathrm{C}$ bond cleavage at the main chain backbone of aldose-MOA (D-glucose-MOA) and ketoses-MOA (D-fructose-MOA) observed in GC/MS EI mode spectra. 
Academic Journal of Research and Scientific Publishing | Vol 2 | Issue 23

Publication Date: 5-3-2021 ISSN: 2706-6495

\begin{tabular}{|c|c|c|c|c|c|}
\hline $\begin{array}{l}\text { Methyloxime- } \\
\text { peracetate }\end{array}$ & $\begin{array}{c}\text { Fragments } \\
\text { Observed }\end{array}$ & \multicolumn{4}{|c|}{ Isotopomer $\mathbf{m} / \mathbf{z}$ values } \\
\hline \multirow{5}{*}{ Glucose } & & $\begin{array}{c}\text { D- } \\
\text { glucose }\end{array}$ & $\begin{array}{c}{\left[1,2-{ }^{13} C_{2}\right] D-} \\
\text { glucose }\end{array}$ & $\begin{array}{c}{\left[\mathrm{U}-^{13} \mathrm{C}_{6}\right] \mathrm{D}-} \\
\text { Glucose }\end{array}$ & $\begin{array}{c}{\left[6-{ }^{13} \mathrm{C}_{1}\right] \mathrm{D}-} \\
\text { glucose }\end{array}$ \\
\hline & C1-C6 & $\mathbf{m} / \mathbf{z}=\mathbf{m}$ & $\mathbf{m} / \mathbf{z}=\mathbf{m}+\mathbf{2}$ & $m / z=m+6$ & $\mathrm{~m} / \mathrm{z}=\mathrm{m}+1$ \\
\hline & $\mathrm{C} 1-\mathrm{C} 5$ & $347(\mathrm{~m})$ & $349(m+2)$ & $352(m+5)$ & $347(\mathrm{~m})$ \\
\hline & $\mathrm{C} 1-\mathrm{C} 2$ & $131(\mathrm{~m})$ & $133(m+2)$ & $133(m+2)$ & $131(\mathrm{~m})$ \\
\hline & C3-C6 & $289(\mathrm{~m})$ & $289(\mathrm{~m})$ & $293(m+4)$ & $290(m+1)$ \\
\hline \multirow{6}{*}{ Fructose } & & $\begin{array}{c}\text { D- } \\
\text { Fructose }\end{array}$ & $\begin{array}{l}{\left[1,2,3-{ }^{13} \mathrm{C}_{3}\right]} \\
\text { D-fructose }\end{array}$ & $\begin{array}{c}{\left[\mathrm{U}^{-13} \mathrm{C}_{6}\right] \mathrm{D}-} \\
\text { fructose }\end{array}$ & \\
\hline & C1-C6 & $\mathbf{m} / \mathbf{z}=\mathbf{m}$ & $\mathbf{m} / \mathbf{z}=\mathbf{m + 3}$ & $m / z=m+6$ & \\
\hline & $\mathrm{C} 1-\mathrm{C} 3$ & $101(\mathrm{~m})$ & $104(m+3)$ & $104(m+3)$ & \\
\hline & $\mathrm{C} 1-\mathrm{C} 3$ & $203(\mathrm{~m})$ & $206(m+3)$ & $206(m+3)$ & \\
\hline & C4-C6 & $115(\mathrm{~m})$ & $115(\mathrm{~m})$ & $118(m+3)$ & \\
\hline & C4-C6 & $217(\mathrm{~m})$ & $217(\mathrm{~m})$ & $220(m+3)$ & \\
\hline
\end{tabular}

Table (2) 
a) D-glucose-MOA EI spectra

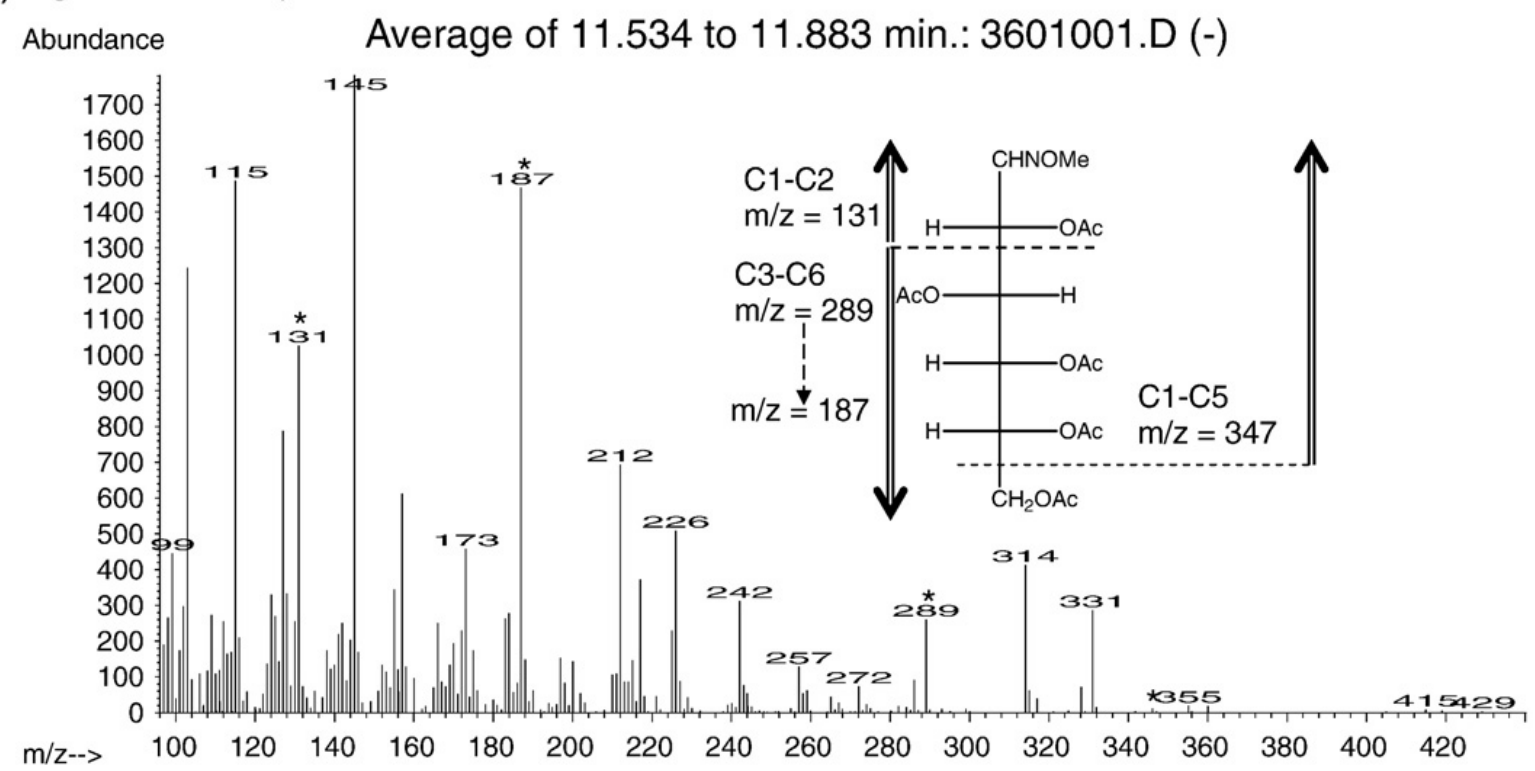

b) D-fructose-MOA El spectra

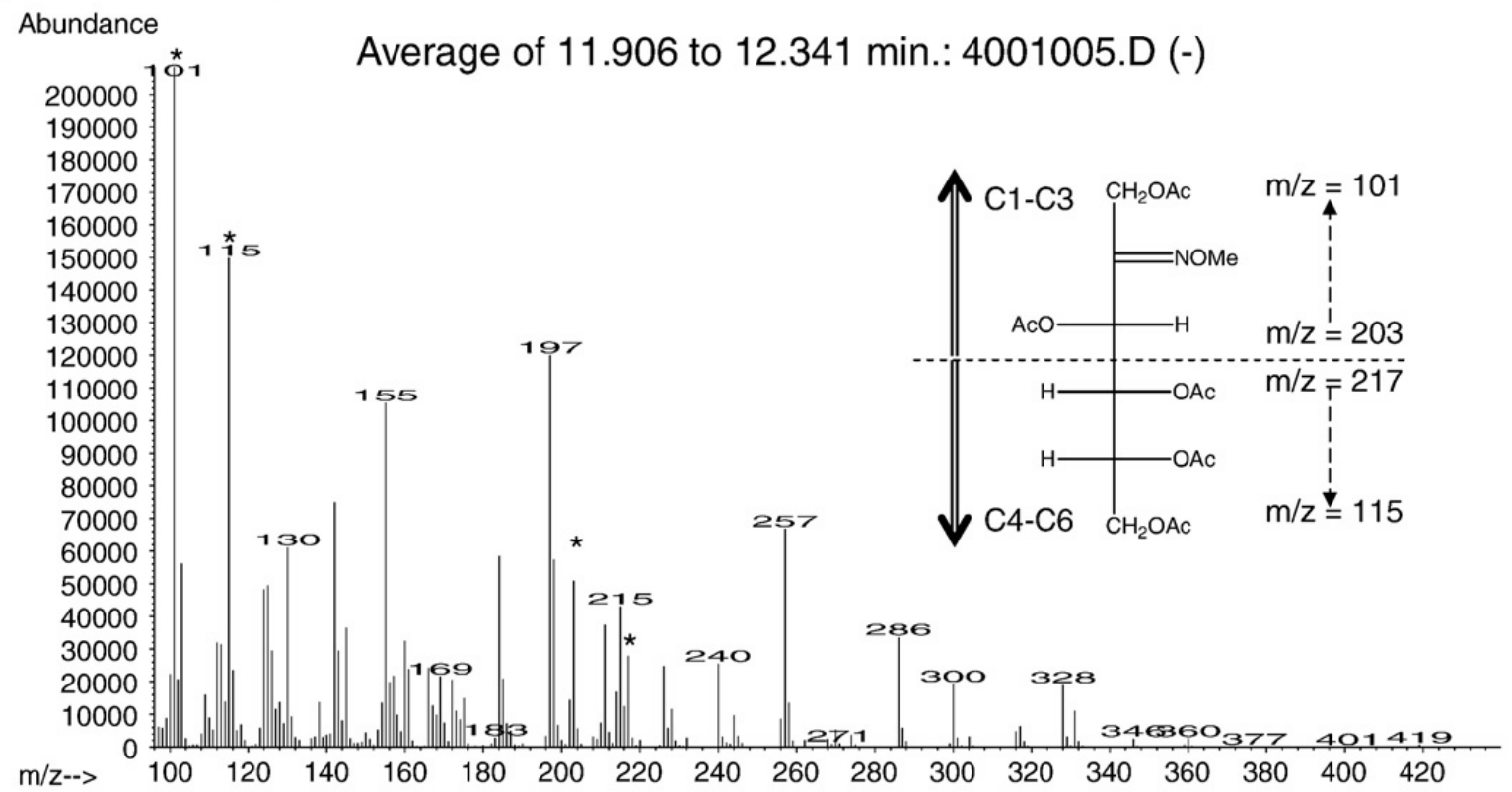

Figure (2) above shows the Mass spectra of fragmentation of aldoses (glucose) and ketoses (fructose) $(\mathrm{m} / \mathrm{z})$.

Knowing the fragmentation of aldo-MOA and keto-MOA is helpful in analysing d-glucose and d-fructose in a mixture because the mass value of unique fragmentation from each molecule can be used as peak identifier along with retention time in gas chromatography.

Glucose shows fragment $\mathrm{C} 1-\mathrm{C} 2$ while fructose was formed $\mathrm{C} 1-\mathrm{C} 3$ and this unique fragments are used in quantitative glucose and fructose in serum sample. 
Typical fragmentation have been obtained from aldo-MOA and keto-MOA have unique retention time and mass fragments which allow GC-MS to quantify them.

Cis and Trans structures of ketoses mono saccharides were solved by GC chromatography. Where the two structures have similar fragmentation but they have different retention time.

\section{Enzymatic quantitative assay of fructose}
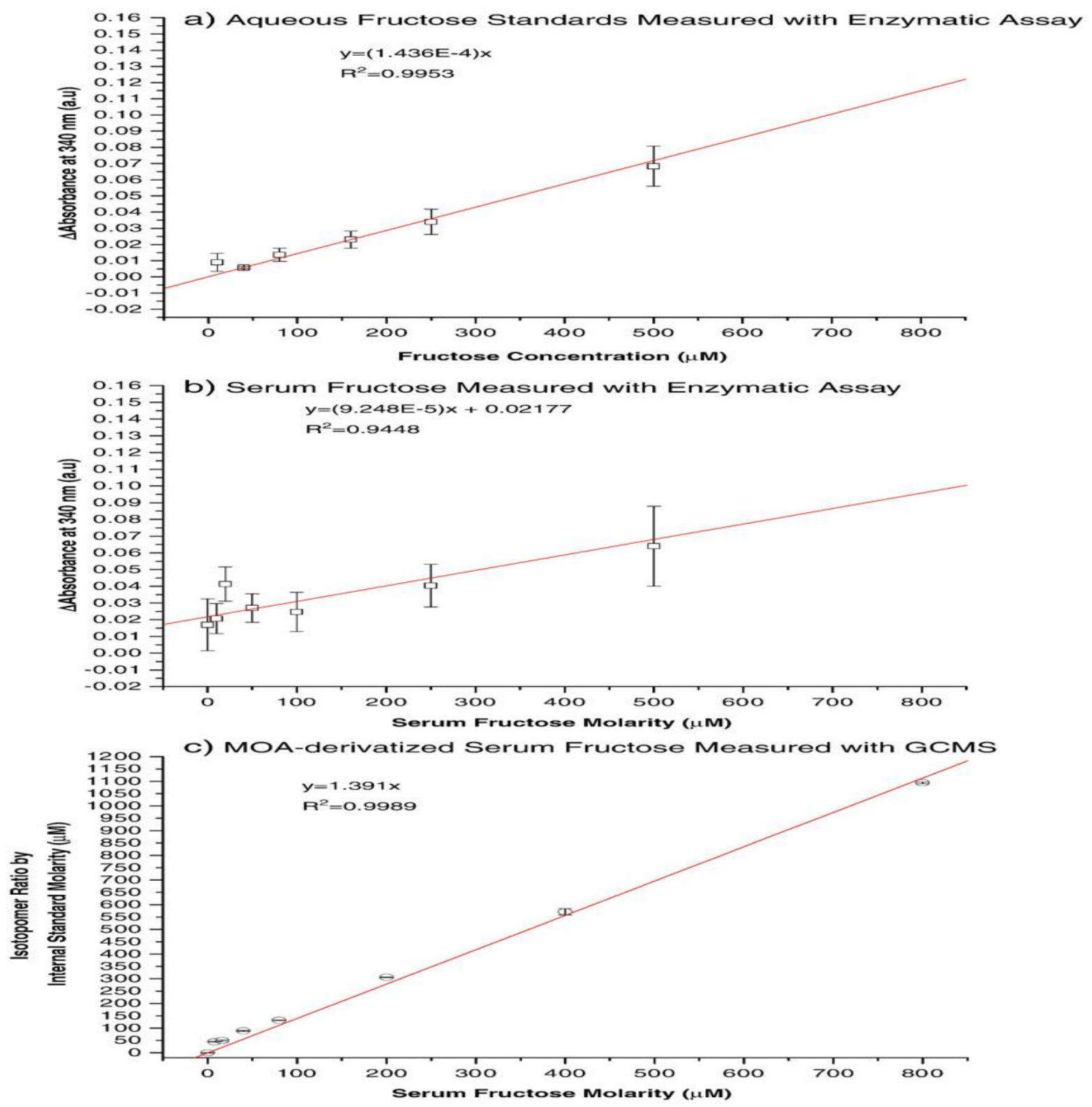

Figure (3) demonstrates the comparison of fructose content by standard curve of fructose in water and in dilapidated and enzymatic method 
For quantitative measurement of fructose by enzymatic assay, standard curve of fructose in water and in dilapidated were obtained and compared with enzymatic method in clinical research which has been published as in figure (3). [9]

\section{2- Analysis of sugars in soil sample from grass field by using GC-MS}

Soil, sediments and aerosols are containing different mixture of organic compound besides containing carbohydrates .never the less, carbohydrates are needed to be converted into their derivatives in order to be analysed by GC-MS.

\section{Experiment procedure}

50 sugar standard including monosaccharaides, disaccharides, sugar alcohols and anhydrosaccharides were prepared and analysed by GC-MS to determine their GC and MS characteristics. MS fragmentations and GC retention time are required for correct identification.

Standard stock solutions (50 sugar compound) were prepared in methanol (120-200 $\mu \mathrm{g} \mathrm{ml}^{-1}$ ). Individual solution of glucose, sorbitol, laevoglucose and sucrose was diluted with methanol to prepare calibration curve $\left(1.2-200 \mu \mathrm{g} \mathrm{ml}^{-1}\right)$ and composite standard solution was prepared (2.4 $100 \mu \mathrm{g} \mathrm{ml}^{-1}$ ) to assess sugar recoveries.

Sugar derivatives were performed by using bis (trimethylsilyl) tri-fluoro acetamide containing $1 \%$ tri-methyl chloro silane and pyridine. Derivatives were evaporated to dryness by $\mathrm{N}_{2}$ then redisssolved in 20-25 $\mu$ l of hexan. $1 \mu \mathrm{l}$ was injected into HP 6890 GC interfaced with HP 5973 Mass selective detector (GC-MS). identification was based on comparing chromatography retention time and mass fragmentation characteristics of the standards with mass spectral library of GC-MS data system, while the quantification of the unknown solution compounds was based on total ion current peak area and converted to compound mass by using calibration curve of external standards ( glucose is used for monosaccharaides, sucrose is used for disaccharides , sorbitol is used for sugar alcohols and laevoglucose is used for anhydro sacharides). 


\section{Result:}
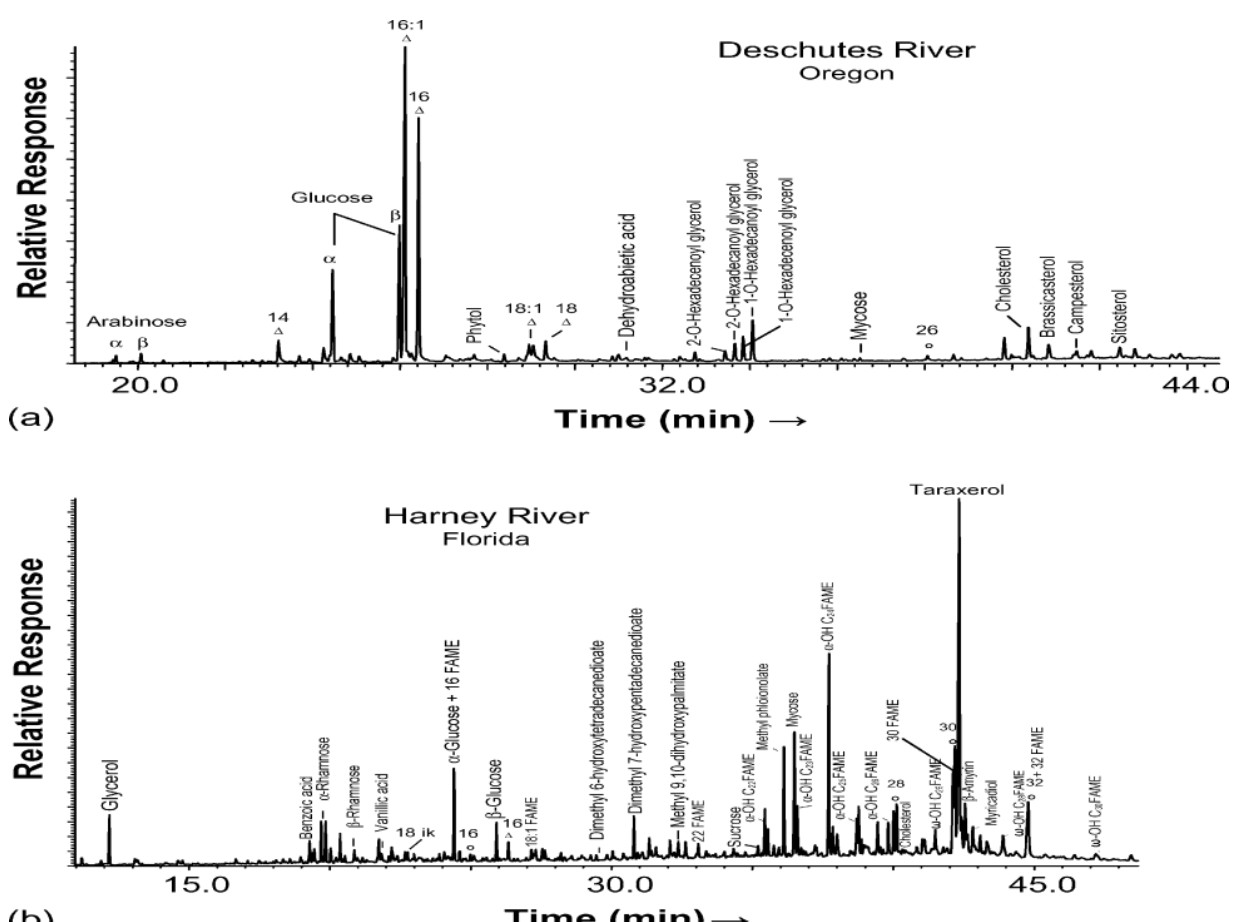

(b)

Time (min) $\rightarrow$
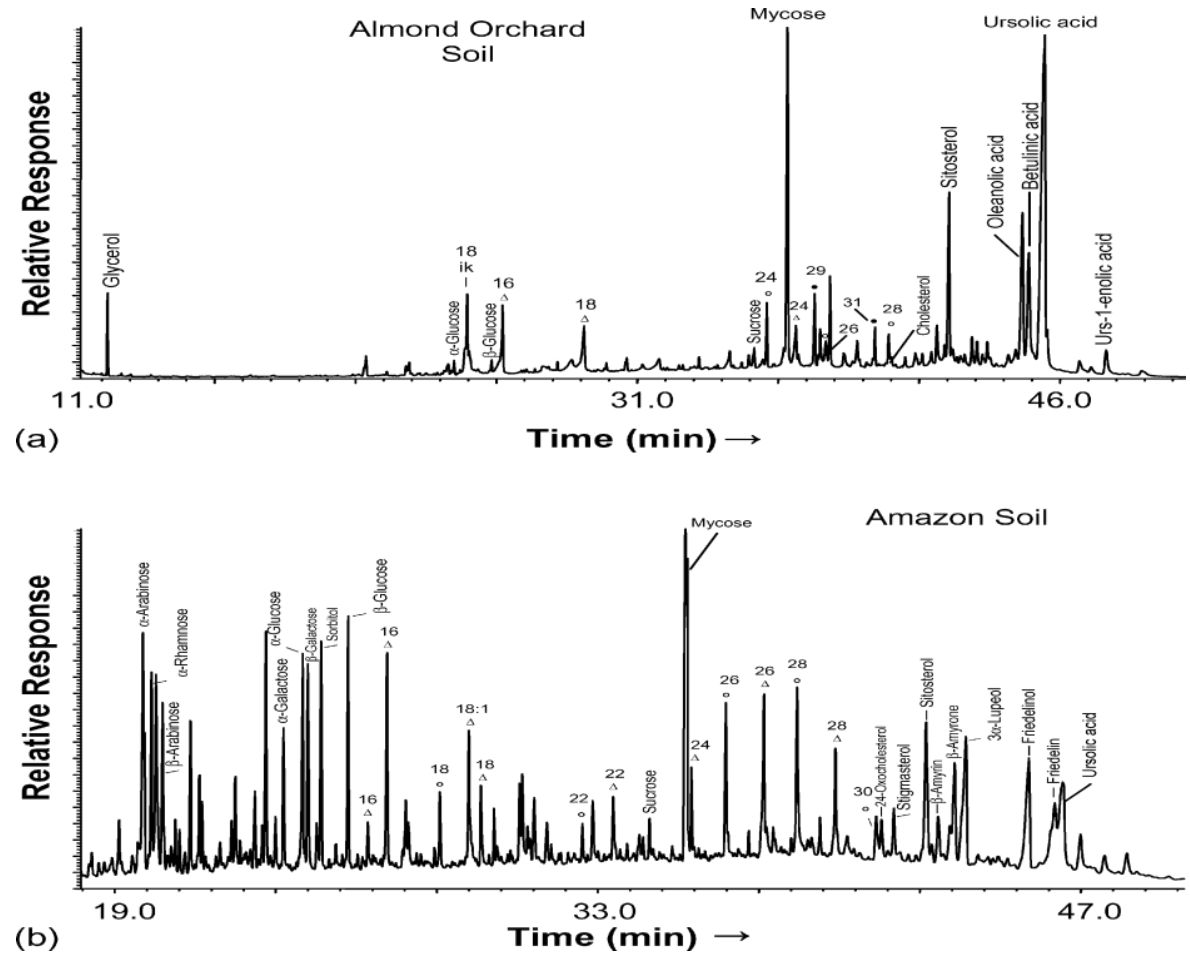

Figure (4) shows the retention time of different sugars 

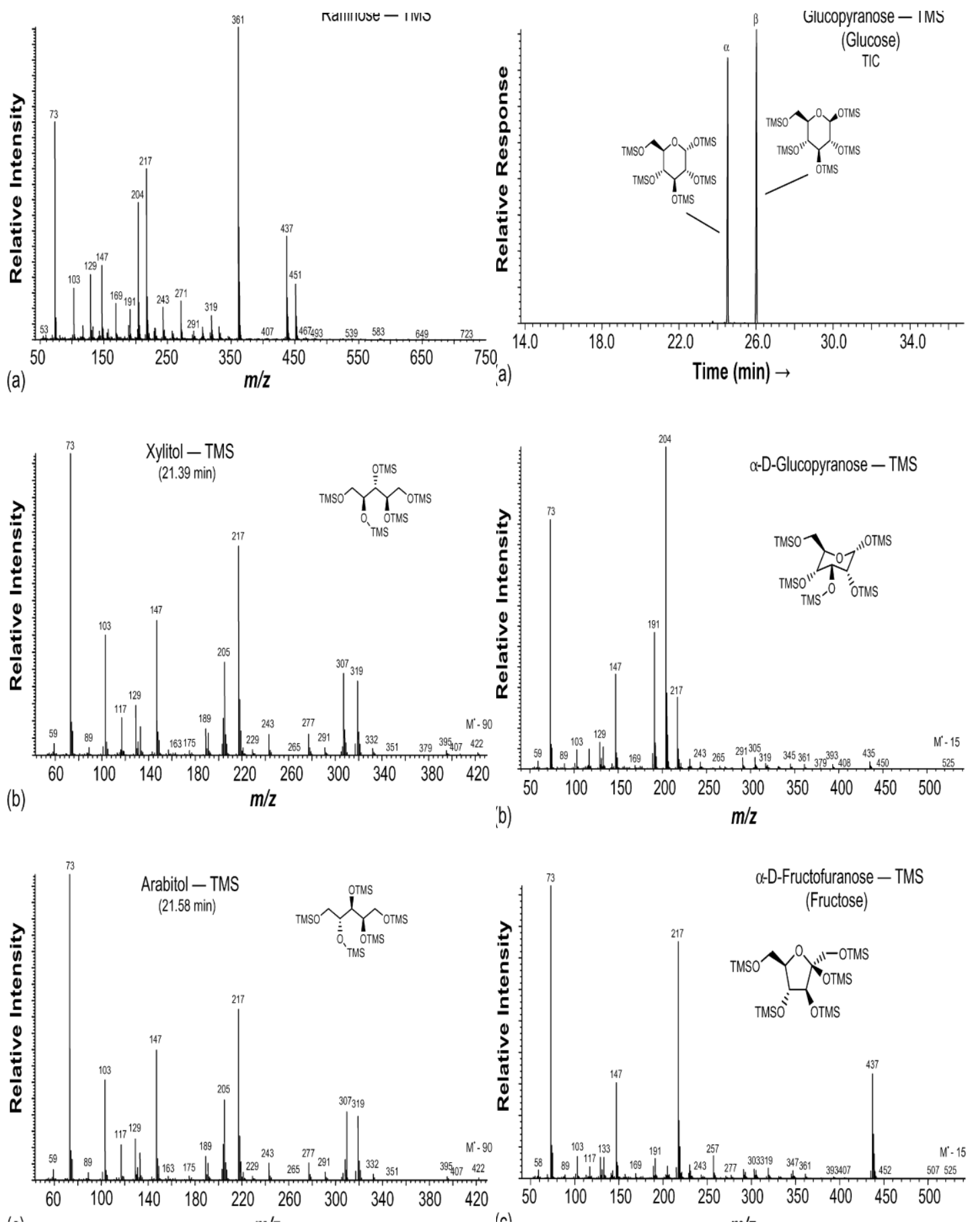

Figure (5) shows the mass fragmentations of monosaccharaides 
Table (3) illustrates the Isotopomer analysis of fragments formed by $\mathrm{C}-\mathrm{C}$ bond cleavage at the main chain backbone of aldo-MOA and keto-MOA observed in GC-MS

\begin{tabular}{|c|c|c|c|c|c|c|c|}
\hline \multicolumn{2}{|c|}{ compound } & \multirow{2}{*}{$\begin{array}{l}\text { Molecul } \\
\text { ar } \\
\text { formula } \\
\text { C5H10O } \\
5\end{array}$} & \multirow{2}{*}{$\begin{array}{l}\text { Molecul } \\
\text { ar mass } \\
150\end{array}$} & \multirow{2}{*}{$\begin{array}{l}\text { Molecul } \\
\text { ar mass- } \\
\text { TMS } \\
438\end{array}$} & \multirow{2}{*}{$\begin{array}{l}\begin{array}{l}\text { Retention } \\
\text { time }\end{array} \\
18.75,18.80\end{array}$} & \multirow{2}{*}{$\begin{array}{l}\mathrm{m} / \mathrm{z} \\
147,218,335\end{array}$} & \multirow{2}{*}{$\begin{array}{l}\begin{array}{l}\text { Kovatsinde } \\
x^{b}\end{array} \\
1603,1605\end{array}$} \\
\hline \multirow{6}{*}{ 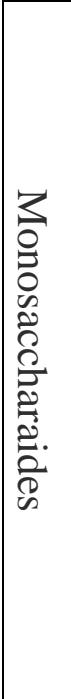 } & D-xylulose & & & & & & \\
\hline & D-ribose & $\begin{array}{l}\text { C5H10O } \\
5\end{array}$ & 150 & 438 & $\begin{array}{l}20.22 \\
20.44\end{array}$ & $217,204,191$ & 1677,1688 \\
\hline & D-fructose & $\begin{array}{l}\text { C6H12O } \\
6\end{array}$ & 180 & 540 & $23.10,23.20$ & $\begin{array}{l}217,437, \\
147\end{array}$ & 1839,1847 \\
\hline & D-glucose & $\begin{array}{l}\text { C6H12O } \\
6\end{array}$ & 180 & 540 & $24.53,26.02$ & $\begin{array}{l}204,191, \\
217\end{array}$ & 1932,2025 \\
\hline & D-mannose & $\begin{array}{l}\text { C6H12O } \\
6\end{array}$ & 180 & 540 & $23.11,23.70$ & $\begin{array}{l}204,191, \\
217\end{array}$ & 1840,1879 \\
\hline & L-sorbose & $\begin{array}{l}\text { C6H12O } \\
6\end{array}$ & 180 & 540 & 24.07 & $\begin{array}{l}204,437, \\
147\end{array}$ & 1903 \\
\hline \multirow{3}{*}{ 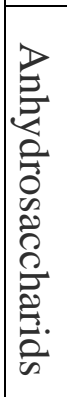 } & Glactosan & $\begin{array}{l}\text { C6H10O } \\
5\end{array}$ & 162 & 378 & 20.31 & $\begin{array}{l}204,217, \\
147\end{array}$ & 1681 \\
\hline & Mannosan & $\begin{array}{l}\text { C6H10O } \\
5\end{array}$ & 162 & 378 & 20.72 & $\begin{array}{l}204,217, \\
333\end{array}$ & 1702 \\
\hline & $\begin{array}{l}\text { Laevoglucos } \\
\text { e }\end{array}$ & $\begin{array}{l}\text { C6H10O } \\
5\end{array}$ & 162 & 378 & 21.11 & $\begin{array}{l}204,217, \\
333\end{array}$ & 1724 \\
\hline \multirow{3}{*}{ 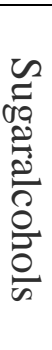 } & Xylitol & $\begin{array}{l}\text { C5H12O } \\
5\end{array}$ & 152 & 512 & 21.39 & $217,307,319$ & 1739 \\
\hline & D-mannitol & $\begin{array}{l}\text { C6H14O } \\
6\end{array}$ & 182 & 614 & 25.22 & $319,205,217$ & 1975 \\
\hline & D-sorbitol & $\begin{array}{l}\text { C6H14O } \\
6\end{array}$ & 182 & 614 & 25.33 & $319,205,217$ & 1981 \\
\hline \multirow{4}{*}{ 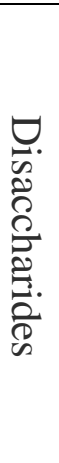 } & D-sucrose & $\begin{array}{l}\text { C12H22 } \\
\text { O11 }\end{array}$ & 342 & 918 & 35.33 & $\begin{array}{l}361,217, \\
437\end{array}$ & 2712 \\
\hline & D-maltose & $\begin{array}{l}\mathrm{C} 12 \mathrm{H} 22 \\
\mathrm{O} 11\end{array}$ & 342 & 918 & 35.82 & $\begin{array}{l}204,361, \\
191\end{array}$ & 2754 \\
\hline & Lactulose & $\begin{array}{l}\mathrm{C} 12 \mathrm{H} 22 \\
\mathrm{O} 11\end{array}$ & 342 & 918 & 35.15 & $\begin{array}{l}204,361, \\
147\end{array}$ & 2697 \\
\hline & lactose & $\begin{array}{l}\mathrm{C} 12 \mathrm{H} 22 \\
\mathrm{O} 11\end{array}$ & 342 & 918 & 35.34 & $\begin{array}{l}204,361, \\
191\end{array}$ & 2713 \\
\hline
\end{tabular}

Table (3) 
Almost all monosaccharaides produced 2 peaks due to $1 \alpha$ and $1 \beta$ configuration of pyrano and furano rings.

Mass spectra of glucopyranose as TMS mainly gives m/z 204 ion fragmentation, while m/z of fructofuranose as TMS $=217$ which might use to identify sugar compounds especially monosaccharaides. But it is difficult to identify MS fragmentation of same group of sugar like galactose and altrose (in this case GC retention time is useful to identify these compound's peaks

The extraction efficiency were determined by comparing peak areas of the sample and those of the standard mixture solution. By calibration curve, the quantification of the sample was determined by comparing the former with the individual standard solutions. [10]

\section{Conclusion}

Using GC-MS to analyse monosaccharaides is common in carbohydrates research. different reaction are required to convert carbohydrates into more volatile derivatives which can be easily isolated by gas chromatography before mass spectrum analysis .the most suitable derivatives of mono saccharides is to convert them into methyl oxime per acetate derivatives MOA or TMS.

Generally, preparation of derivatives for different types of carbohydrate are necessary before GC analysis. Derivatives are used to reduce the number of the peaks in order to obtain better information and structure of the sample.

\section{Reference}

1 - Ho, W. F., B. Stuart and E. R. Prichard (2003). High Performance Liquid Chromatography. Cambridge, GBR, Royal Society of Chemistry.

2- Henriksen, T., Svensmark, B., Lindhardt, B., and Juhler, R. K., Analysis of acidic pesticides using in situ derivatization with alkylchloroformate and solid-phase microextraction (SPME) for GC-MS.Chemosphere, 44, 1531-1539 (2001). Erratum in:Chemosphere, 57, 1037 .((2004

3- Ranz, A; Korpecka, J; Lankmayr, E, 2008. Optimized derivatization of acidic herbicides with tri-methyl silyl diazomethane for GC analysis, Journal of Separation Science, 31: 746752 
4- A. Ruiz-Matute, O. Hernández-Hernández, S. Rodríguez-Sánchez, M. Sanz and I.

Martínez- Castro, 2011.Derivatization of carbohydrates for GC and GC-MS analyses, Journal .of Chromatography B, 879, 1226-1240

5- C. Guivarch and S. Hallegatte, 2013. A survey of urban climate change experiments in .100 cities, Global Environmental Change, 23, 179-192

6- H. Yoon, 2007. Two Step Derivatization for the Analyses of Organic, Amino Acids and .Glycines on Filter Paper Plasma by GC-MS/SIM, Archives of Pharmacal Research, 30, 387-395

7- L. Segovia-Martínez, A. Bouzas-Blanco, P. Campíns-Falcó and A. Seco-Torrecillas, 2010, Improving detection limits for organotin compounds in several matrix water samples by .derivatization-headspace-solid-phase microextraction and GC-MS. Talanta, 80, 1888-1893

8- S. Rodríguez-Sánchez, O. Hernández-Hernández, A. Ruiz-Matute and M. Sanz, 20 11. A derivatization procedure for the simultaneous analysis of iminosugars and other low molecular .weight carbohydrates by GC-MS in mulberry (Morus sp.)Food Chemistry, 126, 353-359

9- P. Wahjudi, M. Patterson, S. Lim, J. Yee, C. Mao and W. Lee, 2010. Measurement of glucose and fructose in clinical samples using gas chromatography/mass spectrometry. Clinical .Biochemistry, 43, 198-207

10- P. Medeiros and B. Simoneit, 2007. Method for the determination of specific molecular markers of biomass burning in Lake Sediments, Journal of Chromatography A, 1141, 271-278

Copyright (C) 2021 Ghayth Mohammed Ghayth, AJRSP. This is an open-access article distributed under the terms of the Creative Commons Attribution License (CC BY NC). https://doi.org/10.52132/Ajrsp/en.2233 